\title{
Maternal Underreporting and the Willett Food Frequency Questionnaire
}

\author{
L. Mullaney ${ }^{1}$, A. O’Higgins ${ }^{2}$, S. Cawley ${ }^{1}$, A. Doolan ${ }^{3}$, D. McCartney ${ }^{1}$ and M.J. Turner ${ }^{2}$ \\ ${ }^{1}$ School of Biological Sciences, Dublin Institute of Technology, Dublin 8, Republic of Ireland, ${ }^{2}$ UCD Centre for Human \\ Reproduction, CWIUH, Dublin 8, Republic of Ireland and ${ }^{3}$ Department of Pediatrics, Trinity College, Dublin 2, \\ Republic of Ireland
}

Dietary misreporting is a well-documented problem in nutritional surveys and may be biased by factors including age, sex, education level, body fat, income level, overweight and obesity ${ }^{(1,2,3,4)}$. It is also established that micronutrient deficits in pregnancy are associated with unfavourable neonatal body composition and other outcomes, for example, low folate status is a critical risk factor for neural tube defect (NTD) births, and for genomic hypomethylation which is associated with increased cancer risk in adulthood ${ }^{(5,6)}$. The purpose of this prospective observational study was to analyse the anthropometric differences between women designated plausible and implausible dietary energy reporters in early pregnancy using the Willet Food Frequency Questionnaire (WFFQ).

Women were recruited at their convenience between February and August 2013 after an ultrasound examination confirmed an ongoing singleton pregnancy. To collect habitual food and nutrient intakes, women were asked to complete a semi-quantitive WFFQ previously validated in pregnancy ${ }^{(7)}$. Maternal body composition was measured using 8-electrode bioelectrical impedance analysis. BMR was calculated using standard equations based on gender, weight, and age ${ }^{(8)}$. Energy intakes were calculated using the WFFQ data and WISP v 4.0 software (Tinuviel Software, Llanfechell, Anglesey, UK). Lowest plausible thresholds for physical activity levels (PAL) were calculated according to respondents' individual reported PAL ${ }^{(9)}$. Those whose ratio of energy intake (EI) to their calculated basal metabolic rate (BMR) (EI/BMR) fell below the calculated plausible threshold for their physical activity category were classified as dietary under-reporters ${ }^{(10)}$. In all categories, those with an EI/BMR greater than 2.5 were classified as dietary over-reporters $^{(11)}$.

The mean age of the total sample $(n=524)$ was $30 \cdot 1$ years, and the mean BMI was $25 \cdot 4 \mathrm{~kg} / \mathrm{m}^{2}$, with $16 \cdot 6 \%$ obese $\left(\mathrm{BMI} \geq 30 \cdot 0 \mathrm{~kg} / \mathrm{m}^{2}\right)$. Under-reported energy intakes were observed in 122 women $(23 \cdot 3 \%)$. There were no over-reporters in the sample. Underreporters were younger than plausible reporters $(p<0 \cdot 001)$. Underreporters were less likely to be of ideal weight (i.e. BMI $\left.18 \cdot 5-24 \cdot 9 \mathrm{~kg} / \mathrm{m}^{2}\right)$ $(p=0.002)$ and were more likely to be obese $(p<0.001)$ than plausible reporters. Underreporters also had higher percentage body fat and lower percentage body fat free mass than plausible reporters $(p<0 \cdot 001)$. Underreporters reported a higher percentage energy intake from carbohydrate than plausible reporters $(p=0.02)$ and also tended to report lower percentages of energy from protein and fat $(p=0.73$ and $p=0 \cdot 14$ respectively).

The increased incidence of under-reporting in overweight and obese women may result in this cohort of women being erroneously identified as being at high nutritional risk. Given the importance of maternal diet in fetal development and in later infant and adult health, all women in pregnancy who may be at risk of nutritional deficiencies or excesses need to be accurately identified so that effective interventions can be implemented.

1. Samaras K, Kelly PJ, Campbell LV (1991) Int J ObesRelatMetabDisord 23, 881-8.

2. Scagliusi FB, Ferriolli E, Pfrimer K, Laureano C, Cunha CSF, Gualano B, et al. (2009) Eur J ClinNutr 63, 1192-1199.

3. Shaneshin M, Ashidkhani B, Rabiei S (2012) Arch Iran Med 15, 681-687.

4. McGowan CA, McAuliffe FM (2012) Eur J ClinNutr 66, 906-913.

5. MRC Vitamin Study Research Group (1991) Lancet 338, 131-7.

6. Ciappio ED, Liu Z, Brooks RS, Mason JB, Bronson RT, Crott JW (2011) Gut 60, 1695-702.

7. McGowan CA, Curran S, McAuliffe FM (2013) J Hum Nutr Diet [Epub ahead of print]

8. Henry CJ (2005) Public Health Nutr 8, 1133-52.

9. Black AE (2000) Int J ObesRelatMetabDisord 24, 1119-1130.

10. Goldberg GR, Black AE, Jebb SA, Cole TJ, Murgatroyd PR, Coward WA et al. (1991) Eur JClinNutr 45, 569-581.

11. Black AE, Coward WA, Cole TJ, Prentice AM (1996) Eur JClinNutr 50, 72-92. 